\title{
STRESS COPING STRATEGIES AT UNIVERSITY STUDENTS - PART I: GENDER DIFFERENCES
}

\section{Hana Chýlová, Ludmila Natovová}

\begin{abstract}
The aim of present study is to investigate the particularities of using various stress coping strategies by undergraduate students at the Czech University of Life Sciences (CULS) with a special regard to the balance between positive and negative stress coping strategies, and resulting consequences. Authors focused on comparing differences in the use of coping strategies between standardized scores of the Czech population and student population, as well as on identifying differences in the use of coping strategies between both genders. The data were collected using the standardized stress coping strategies questionnaire - SVF 78. Of the total number of 177 students, 63 were male and 114 were female undergraduate students of Faculty of Economics and Management (FEM) at CULS. The most important outcome of the current study research is a proven significant distinction between the positive-negative stress coping strategies employed by CULS undergraduate students and those of the Czech population sample. From the global point of view, the use of positive stress coping techniques seems comparatively high and might therefore be considered as satisfactory. However, significantly lower use of the most constructive and, in longer prospective, most approved group of strategies is rather disappointing.
\end{abstract}

\section{Key Words}

Coping strategy, Czech population sample, gender, stress, university education
Czech University of Life Sciences Prague chylova@pef.czu.cz

ARTICLE INFO

Article type

Full research paper

doi: 10.7160/eriesj.2012.050303

Article history

Received: April 30, 2012

Received in revised form: June 30, 2012

Accepted: July 28, 2012

Available on-line: September 30, 2012

Chýlová, H., Natovová, L. (2012) "Stress Coping Strategies at University Students - Part I: Gender Differences", Journal on Efficiency and Responsibility in Education and Science, Vol. 5, No. 3, pp. 135-147, ISSN 1803-1617, [on-line] www.eriesjournal.com/_papers/article_172.pdf [2012-09-30]. doi: 10.7160/eriesj.2012.050303 


\section{Introduction}

University studies place numerous demands on students' personality - their cognition, character, motivational processes, etc. Naturally, during their studies a number of various stress situations occur, especially in connection with achievement expectations, stress reduction, interpersonal relationships, solving personal problems in relevant levels of corresponding developmental stage. The associations of personality, affect, trait emotional intelligence and coping style measured at the start of the academic year with later academic performance were examined in a group of undergraduate students by Saklofske et al. (2012). Modelling for stress and life satisfaction showed relationships with personality, affect, and the task focus and emotion regulation factors. The high levels of demands put on students often lead into a high level of perceived distress and difficulties. Topics on such problematic area were presented at the ERIE conference by studies conducted by Chamoutová and Chýlová (2008) or Millerová, Michálek and Franco Ruiz (2007). Studies focused on relation between the uses of different stress coping strategies by full-time university students. Results showed that students' lives were perceived as highly demanding and stressful. These findings required further investigation, which created a baseline for the currently presented study. The study focuses on a comparison of stress coping strategies at university students in contrast to the Czech population sample. The comparative analysis is complemented by an analysis of gender differences in a use of stress coping strategies. The comparative analysis of other variables in relation to stress coping strategies will be presented in the Part - II of this paper.

Czech as well as foreign academic literature usually describes coping strategies as strategies used for coping with stress (e.g. Aldwin and Yancura, 2011; Kebza, 2005; Janke and Erdmann,
2003). Authors follow the classical concept of stress proposed by Hans Selye (1950). We may come across the following description of coping: "...coping denotes the psychological operations, both conscious and unconscious, being applied by an individual in order to manage demands of stressful situation or event" (Balcar, Trnka and Kuška, 2011, p. 27). The same authors believe that coping strategies comprise of cognitive, emotional, behavioural, and physiological processes implemented in various combinations that are selectively and purposefully effective in order to ease individual's demand overload.

Next to the term "coping strategies' there is a frequently used term "coping styles'; both of which have been used in similar sense. According to Aldwin and Yancura (2011, p. 267) coping style approach assumes that "...there is an intra-individual stability in the use of coping styles throughout various situations." Therefore, we may assume that tendencies to employ similar coping strategies throughout different lifetime events might be considered an invariable characteristic, detectable within individual psycho-diagnosis (Janke and Erdmann, 2003). Authors (in accordance with Aldwin and Yancura (2011) perceive coping styles in a broader sense (related to personal characteristic) than coping strategies (related to actual behaviour, for further information see for example Eduardo Piemontesi et al., 2012; Shankland et al., 2010). However, especially in the context of the stress coping strategies questionnaire SVF 78 by Janke and Erdmann (2003), which is in detail described in the Method section, the term stress coping strategies is considered to be adequate.

As defined by researchers, there are distinct typologies within the field of stress coping strategies; such as active and passive coping (Gerin, 2011) or strategies leading towards 
stress reduction - positive stress coping strategies, in contrast to strategies leading to increase of stress - so called negative strategies (Weyers, Ising and Janke, 2005).

There are undoubtedly various approaches to coping with distress and yet, it is possible to distinguish, at least, the two major strategy groups - the positive and negative ones. However, the choice of applied coping strategy may differ in relation to specific factors, e.g. demographic indicators - gender, education level, age - or personal characteristics (namely neuroticism mentioned in Horáková, 2009 or anxiety, as Eduardo Piemontesi et al. state, 2012). Lukavský, Šolcová and Preiss (2011) came to similar findings while exploring proactive stress coping strategies; according to their research women show higher need for emotional support while men tend to apply reflective solution to a problematic situation. Research results point out gender differences in search for an instrumental support angle, even though the statistical significance of this trend has not been fully validated (also in Šolcová, Lukavský, and Greenglass, 2006). On the contrary, according to Contrada and Baum (2011) coping strategies, in general, might be considered being male-female dependent. Coping strategies have been clustered into distinct categories based on a variety of conceptual and empirical considerations, perhaps the most influential distinction for investigations of gender differences is the one proposed by Lazarus and Folkman (1984). They classified coping responses as either problem focused coping or emotion focused coping. Women reported significantly greater use of problem focused (active coping) and emotion focused strategies (rumination) as well as social support seeking in comparison to men. Women endorse more strategies to cope with stress than men do, including those considered gender-role consistent (emotion oriented, support seeking) and inconsistent (active, problem focused). In connection with university education, Shankland et al. (2010, p. 354) state that „...problem-focused coping strategies are more effective in facing controllable situations, like coping with the demands of student life, while the emotion-focused strategies are more effective in facing unmanageable events".

The aim of present study is to investigate the particularities of using various stress coping strategies by undergraduate students at the Czech University of Life Sciences (CULS) with a special regard to the balance between positive and negative stress coping strategies, and resulting consequences. Authors focused on comparing differences in the use of coping strategies between standardized scores of the Czech population and student population, as well as on identifying differences in the use of coping strategies between both genders. One way to measure coping, as mentioned earlier, is when considered a habitual trait, characterizing the individual's reaction, independently from the kind of stressful situation (Ising et al., 2006). Inventories following this approach are, for example, the COPE inventory (Carver, Scheier and Weintraub, 1989), the Stressverarbeitungsfragenbogen SVF 120 (Janke and Erdmann, 2005) and its variant SVF 78 (Janke and Erdmann, 2003). Authors of this study followed this concept too. The data were collected using a standardized method - SVF 78 (Janke and Erdmann, 2003). The questionnaire consisted of 13 scales - 7 scales for positive stress coping strategies, 2 neutral, and 4 negative strategies. Each one of the scales can be interpreted on its own and compared to the Czech standardized tables, which enable researchers to assess the differences in using coping techniques within the specific group of CULS undergraduate students.

The SVF 78 questionnaire, focusing at the mapping of stress coping strategies, has proved to be highly useful instrument, 
especially in the contemporary information society with incessantly increasing level of stress. In addition, the ways of coping with stress are nowadays frequently not the constructive ones. The population of university students is very illustrative example of both mentioned cases - of high level of stress and in the same time of high level of non-constructive ways of coping. From the point of view of the psychological counsellor, the qualified and reliable description of contemporary trends in stress coping strategies within the youth population is most welcome (it is necessary, for example, for prevention of the drug and alcohol abuse and more tailored aiming of respective psychological lectures and seminars) and is well in accord with responsible system of education.

\section{Materials and Methods}

\section{Group of respondents}

The data were collected during autumn/winter semester of academic year 2011/2012 on a sample of first and second year undergraduate students of Faculty of Economics and Management (FEM) at CULS ( $=177)$. Students in our group of respondents represent both forms of studies -75 students were full-time students, 102 students were part-time students. Of the total number of 177 students, 63 were male and 114 were female students, within the study programmes Public Administration and Regional Development and Business and Administration. The average age was 26 years. Descriptive characteristics of our respondent group are shown in more detail in Table 1, below.

\begin{tabular}{|c|c|c|c|c|c|c|c|c|}
\hline 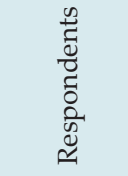 & Z & $\begin{array}{l}\tilde{\Xi} \\
\underset{\Xi}{\Xi} \\
\underset{\Xi}{\Xi}\end{array}$ & 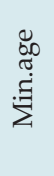 & 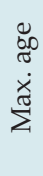 & 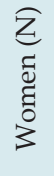 & 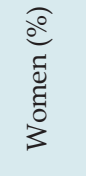 & $\begin{array}{l}\widehat{Z} \\
\stackrel{\Xi}{\tilde{J}}\end{array}$ & $\frac{\overparen{\varrho}}{\overbrace{\Sigma}^{\varrho}}$ \\
\hline $\begin{array}{l}\text { Part-time } \\
\text { students }\end{array}$ & 102 & 30,17 & 20 & 49 & 52 & 50,98 & 50 & 49,02 \\
\hline $\begin{array}{l}\text { Full-time } \\
\text { students }\end{array}$ & 75 & 20,89 & 19 & 26 & 62 & 82,67 & 13 & 17,33 \\
\hline Total & 177 & 26,24 & 19 & 49 & 114 & 64,41 & 63 & 35,59 \\
\hline
\end{tabular}

Tab. 1: Descriptive characteristics of group of respondents.

Respondents participated voluntarily, and were not paid. The testing via SVF 78 questionnaire was positively accepted, as students get immediate feedback on their results, receiving this way (anonymously) the comments and recommendations on their stress coping behaviour together with experience with the use of psychological instrument of high psychometric quality. The issue of stress is quite popular and there are, in general, no obstacles to imagine and describe real life situations of stress events and coping with them.

The method

SVF 78 (Janke and Erdmann, 2003) is a German questionnaire based on a trait approach, fully standardized into Czech language and cultural environment. This method was used to obtain data on different stress coping strategies. The standard Czech version of the aforementioned questionnaire was applied with the following instruction: "When I am disturbed, irritated, or upset by something or someone...." 


\begin{tabular}{|c|c|c|c|c|}
\hline Subtest & $\begin{array}{l}\text { Description } \\
\text { of } \\
\text { subcategories }\end{array}$ & $\begin{array}{l}\text { Name of } \\
\text { strategy }\end{array}$ & $\begin{array}{l}\text { Abbreviated } \\
\text { name of } \\
\text { strat. }\end{array}$ & Sample-item \\
\hline \multirow{2}{*}{ 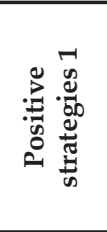 } & \multirow{2}{*}{$\begin{array}{l}\text { Devaluation / } \\
\text { Defence }\end{array}$} & $\begin{array}{l}\text { Minimi- } \\
\text { zation }\end{array}$ & MIN & $\begin{array}{l}\text { I tell myself that } \\
\text { everything will turn } \\
\text { out all right. }\end{array}$ \\
\hline & & $\begin{array}{l}\text { Denial of } \\
\text { guilt }\end{array}$ & DENGU & $\begin{array}{l}\text { I think that I am not } \\
\text { responsible for the } \\
\text { situation. }\end{array}$ \\
\hline \multirow{2}{*}{ 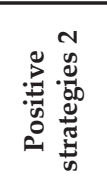 } & \multirow[b]{2}{*}{ Distraction } & Distraction & DISTR & $\begin{array}{l}\text { I try to distract } \\
\text { myself. }\end{array}$ \\
\hline & & $\begin{array}{l}\text { Substitute } \\
\text { gratification }\end{array}$ & SUB & $\begin{array}{l}\text { I grant myself } \\
\text { something I've desired } \\
\text { for a long time. }\end{array}$ \\
\hline \multirow{2}{*}{ 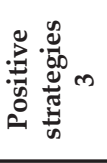 } & \multirow{2}{*}{$\begin{array}{l}\text { Control / } \\
\text { Constructive }\end{array}$} & $\begin{array}{l}\text { Response } \\
\text { control }\end{array}$ & RECON & $\begin{array}{l}\text { I tell myself not to } \\
\text { lose my temper. }\end{array}$ \\
\hline & & $\begin{array}{l}\text { Positive self- } \\
\text { instructions }\end{array}$ & POSI & $\begin{array}{l}\text { I tell myself that I can } \\
\text { cope with it. }\end{array}$ \\
\hline \multirow{2}{*}{ 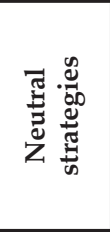 } & \multirow{2}{*}{$\begin{array}{l}\text { Neutral / } \\
\text { Situation } \\
\text { dependent }\end{array}$} & $\begin{array}{l}\text { Need for } \\
\text { social } \\
\text { support }\end{array}$ & SOCSUP & $\begin{array}{l}\text { I try to talk with } \\
\text { someone about the } \\
\text { problem. }\end{array}$ \\
\hline & & Avoidance & AVOID & $\begin{array}{l}\text { I resolve to avoid } \\
\text { such situations in the } \\
\text { future. }\end{array}$ \\
\hline \multirow{4}{*}{ 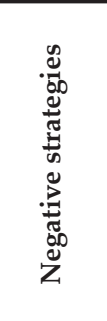 } & \multirow{4}{*}{ Negative } & Negative & ESC & $\begin{array}{l}\text { I tend to run away } \\
\text { from the situation. }\end{array}$ \\
\hline & & Rumination & RUMI & $\begin{array}{l}\text { I keep on thinking } \\
\text { about the situation } \\
\text { for a long time, } \\
\text { afterwards. }\end{array}$ \\
\hline & & Resignation & RES & I tend to give up. \\
\hline & & Self-blame & SEBLA & I blame myself. \\
\hline
\end{tabular}

Tab. 2: SVF 78 Subtests and Categories (Weyers et al, 2005).
Stress coping techniques were assessed according to two major groups of subtests (for details see Table 2): The first seven subtests, which in principal can be considered to reduce stress, are grouped under the category of Positive strategies total and can be divided into following subcategories: Devaluation/ Defence (Positive strategies1, from Minimization to Denial of guilt), Distraction (Positive strategies 2, from Distraction to Substitute gratification) and Control (Positive strategies 3, from Situation control to Positive self-instructions). The four remaining subtests ranging from Escape to Self-blame are considered to augment rather than reduce stress; these subtests are grouped under the category of Negative strategies total. There can be identified two more strategies, which are referred to as Neutral strategies, as no definite affiliation towards positive or negative side can be identified, these strategies must be, in all cases, viewed as situation dependent.

From the psychometric characteristics' point of view, the SVF 78 provides high level of reliability and time stability, consistent construct validity, and considerable external validity in regards to other stress coping inventories (Janke and Erdmann, 2003; Weyers et al, 2005).

\section{Statistical Analyses}

Next to the descriptive analysis, of which the main aim is to describe the field of interest and to classify respective items (Disman, 2008), a thorough examination of relation between variables was executed. The independent variables are: the Test values (the Mean value of SVF 78 found in the standardized table outputs for each Subtest for the whole Czech population sample and separate scores for males and females). The dependent variable was the stress coping strategy usage measured by the SVF 78 on a sample of CULS students. 
In order to ascertain the nature of relation between the two variables, authors decided to test the null hypothesis to find out whether the sample comes from a population with the same Mean value as the Test value - therefore one sample t-test was computed, using SPSS 19 statistics software (Norušis, 2011). For additional assessment of the differences in usage of stress coping strategies at males and females, we have formulated a hypothesis on the statistically significant differences in the use of coping strategies between the group of male students and the group of female students, identified through the SVF 78 questionnaire. To test this second null hypothesis of nonexistence of a significant difference between the two groups, we used a t test for two independent samples (Norušis, 2011), and before each testing, the null hypothesis of no difference in the variance of the evaluated variable values in both groups was adopted based on Levene's test for equality of variances.

\section{Results}

Results of the most important descriptive statistics of the observed subcategories - Positive strategies 1, Positive strategies 2 and Positive strategies 3 and categories - Positive strategies in total, Negative strategies in total, as well as the results of the computation of one-sample t-test (data obtained from CULS students compared to Test value of Czech population sample in respective categories and subcategories) are displayed in Table 3 , below.

\begin{tabular}{|c|c|c|c|c|c|c|c|c|c|}
\hline \multirow[t]{2}{*}{ Strategy } & \multirow[t]{2}{*}{$\stackrel{\Xi}{\stackrel{\Xi}{\Sigma}}$} & \multirow{2}{*}{$\begin{array}{l}\text { वें } \\
\text { के }\end{array}$} & \multirow{2}{*}{ 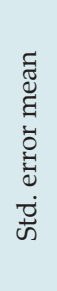 } & \multirow{2}{*}{ 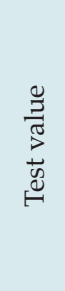 } & \multirow[t]{2}{*}{+} & \multirow{2}{*}{ 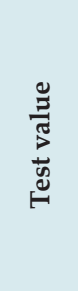 } & \multirow{2}{*}{ 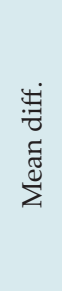 } & \multicolumn{2}{|c|}{$\begin{array}{c}95 \% \\
\text { Confidence } \\
\text { interval } \\
\text { of the } \\
\text { difference }\end{array}$} \\
\hline & & & & & & & & $\begin{array}{l}\dot{0} \\
3 \\
0 \\
\end{array}$ & $\frac{\bar{\nu}}{2}$ \\
\hline $\begin{array}{l}\text { Positive } \\
\text { strategies } 1\end{array}$ & 11,10 & 3,76 & 0,28 & 10,09 & 3,58 & $0,00^{* *}$ & 1,01 & 0,45 & 1,57 \\
\hline $\begin{array}{l}\text { Positive } \\
\text { strategies } 2\end{array}$ & 12,26 & 3,54 & 0,27 & 10,37 & 7,1 & $0,00^{* *}$ & 1,89 & 1,37 & 2,42 \\
\hline $\begin{array}{l}\text { Positive } \\
\text { strategies } 3\end{array}$ & 15,57 & 3,59 & 0,27 & 16,19 & $-2,3$ & $0,02^{*}$ & $-0,62$ & $-1,15$ & $-0,09$ \\
\hline $\begin{array}{l}\text { Positive } \\
\text { strategies } \\
\text { total }\end{array}$ & 13,35 & 2,74 & 0,21 & 12,22 & 5,48 & $0,00^{* *}$ & 1,13 & 0,72 & 1,53 \\
\hline $\begin{array}{l}\text { Negative } \\
\text { strategies } \\
\text { total }\end{array}$ & 12,04 & 4,16 & 0,31 & 10,52 & 4,86 & $0,00^{* *}$ & 1,52 & 0,9 & 2,13 \\
\hline
\end{tabular}

Tab. 3: Results - descriptive statistics and one sample t-test

Table 3 illustrates that Means of the data from our group of respondents differ from those of the Czech population sample (Test value); in all five cases there is a variation within one standard deviation from the Mean in question. In order to test the null hypothesis of non-significance in variation between the two Means, one sample t-test was computed and its results are displayed in Table 3. Results demonstrate the significance level to be, in one case, less than 0,05 ; in other cases less than $0,01$. Our observed results are very unlikely in all five cases; therefore the null hypothesis was rejected. Our sample probably comes from a population with a larger Mean than the examined Test value; except for the Positive strategies 3, where the computed 
$\mathrm{t}$-test is negative, and therefore it is expected for the mean value of our sample to be lower than the population sample.

These results indicate tendency towards increased usage of most stress coping technique subcategories, in general, both positive as well as negative ones.

The results also show some differences in preference of employing specific subcategories of positive stress coping strategies, especially those connected to devaluation, defence and distraction in contrast to low level usage of constructive positive strategies.

Presumably influenced by relatively low age, the considered group of participants is still indecisive when it comes to choosing a stress coping strategy; together with large group of students, who employ positive, but in a long term view short-sighted stress coping strategies. Detailed analysis of the results shows further possibilities when it comes to strengthening the positive strategies and forming more suitable strategies compared to the currently preferred ones. Targeted influence and training might help to form more resistant stress coping individuals, able to better sustain permanent stress induced by highly demanding work environment.

Let us have a closer look on comparison of differences in the use of coping strategies by male-students and female-students compared with the values of the Czech standardization sample. More details are shown in Table 4, below.

\begin{tabular}{|c|c|c|c|c|c|c|c|c|c|c|}
\hline \multirow{2}{*}{ 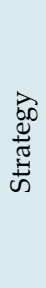 } & \multirow{2}{*}{ 悹 } & \multirow[t]{2}{*}{$\stackrel{\text { జే }}{\stackrel{\Xi}{\Sigma}}$} & \multirow{2}{*}{$\begin{array}{l}\overrightarrow{0} \\
0 \\
\text { वें } \\
\text { के }\end{array}$} & \multirow{2}{*}{ 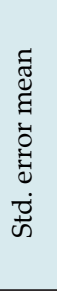 } & \multicolumn{3}{|c|}{ One sample $t$ test } & \multirow{2}{*}{ 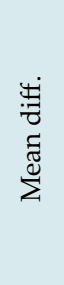 } & \multicolumn{2}{|c|}{$\begin{array}{c}95 \% \\
\text { Confidence } \\
\text { interval } \\
\text { of the } \\
\text { difference }\end{array}$} \\
\hline & & & & & 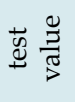 & $\mathrm{t}$ & Sig. & & $\begin{array}{l}\overline{0} \\
\text { ż } \\
0\end{array}$ & $\frac{\vec{\otimes}}{\frac{\partial}{2}}$ \\
\hline \multirow{2}{*}{ 当 } & Male & 13,3 & 4,92 & 0,62 & 10,67 & 4,25 & $0,00^{* *}$ & 2,63 & 1,4 & 3,87 \\
\hline & Female & 9,49 & 4,96 & 0,46 & 8,18 & 2,82 & $0,01^{* *}$ & 1,31 & 0,39 & 2,23 \\
\hline \multirow{2}{*}{ 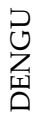 } & Male & 11,78 & 3,56 & 0,45 & 11,41 & 0,82 & 0,42 & 0,37 & $-0,53$ & 1,27 \\
\hline & Female & 11,13 & 4,25 & 0,4 & 9,99 & 2,85 & $0,01^{* *}$ & 1,13 & 0,35 & 1,92 \\
\hline \multirow{2}{*}{$\begin{array}{l}\stackrel{\sigma}{ज} \\
\stackrel{⿹}{0}\end{array}$} & Male & 12,33 & 4,01 & 0,51 & 11,69 & 1,27 & 0,21 & 0,64 & $-0,37$ & 1,65 \\
\hline & Female & 13 & 4,06 & 0,38 & 11,97 & 2,71 & $0,01^{* *}$ & 1,03 & 0,28 & 1,78 \\
\hline \multirow{2}{*}{ 占 } & Male & 11,19 & 4,2 & 0,53 & 8,42 & 5,24 & $0,00^{* *}$ & 2,77 & 1,71 & 3,83 \\
\hline & Female & 12,08 & 4,34 & 0,41 & 9,42 & 6,54 & $0,00^{* *}$ & 2,66 & 1,85 & 3,46 \\
\hline \multirow{2}{*}{ 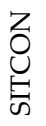 } & Male & 15,87 & 4,18 & 0,53 & 16,84 & $-1,84$ & 0,07 & $-0,97$ & $-2,02$ & 0,08 \\
\hline & Female & 15,82 & 4,09 & 0,38 & 16,72 & $-2,36$ & $0,02^{*}$ & $-0,9$ & $-1,66$ & $-0,14$ \\
\hline \multirow{2}{*}{ 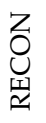 } & Male & 16,16 & 3,82 & 0,48 & 15,27 & 1,85 & 0,07 & 0,89 & $-0,07$ & 1,85 \\
\hline & Female & 15,11 & 3,79 & 0,35 & 15,56 & $-1,28$ & 0,2 & $-0,45$ & $-1,16$ & 0,25 \\
\hline
\end{tabular}




\begin{tabular}{|c|c|c|c|c|c|c|c|c|c|c|}
\hline \multirow{2}{*}{ 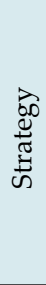 } & \multirow{2}{*}{$\begin{array}{l}\overrightarrow{0} \\
\frac{\tilde{D}}{0} \\
0\end{array}$} & \multirow[t]{2}{*}{$\stackrel{\Xi}{\Xi}$} & \multirow{2}{*}{$\begin{array}{l}\overrightarrow{0} \\
\text { च } \\
\text { के }\end{array}$} & \multirow{2}{*}{ 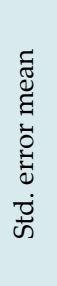 } & \multicolumn{3}{|c|}{ One sample $t$ test } & \multirow{2}{*}{ 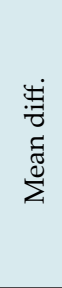 } & \multicolumn{2}{|c|}{$\begin{array}{l}95 \% \\
\text { Confidence } \\
\text { interval } \\
\text { of the } \\
\text { difference }\end{array}$} \\
\hline & & & & & 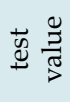 & $\mathrm{t}$ & Sig. & & $\begin{array}{l}\overline{0} \\
\vdots \\
0\end{array}$ & $\begin{array}{l}\overline{\tilde{\nu}} \\
\frac{2}{2}\end{array}$ \\
\hline \multirow{2}{*}{$\begin{array}{l}\text { ⿹ } \\
0 \\
\end{array}$} & Male & 15,84 & 5,03 & 0,63 & 16,71 & $-1,37$ & 0,18 & $-0,87$ & $-2,13$ & 0,4 \\
\hline & Female & 15,14 & 4,58 & 0,43 & 16,02 & $-2,05$ & $0,04^{*}$ & $-0,88$ & $-1,73$ & $-0,03$ \\
\hline \multirow{2}{*}{ 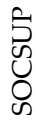 } & Male & 13,83 & 5,06 & 0,64 & 11,57 & 3,54 & $0,00^{* *}$ & 2,26 & 0,98 & 3,53 \\
\hline & Female & 16,29 & 4,77 & 0,45 & 14,23 & 4,61 & $0,00^{* *}$ & 2,06 & 1,18 & 2,94 \\
\hline \multirow{2}{*}{$\begin{array}{l}\stackrel{2}{0} \\
\stackrel{2}{\gtrless}\end{array}$} & Male & 14,97 & 4,42 & 0,57 & 11,44 & 6,33 & $0,00^{* *}$ & 3,53 & 2,41 & 4,64 \\
\hline & Female & 15,13 & 4,3 & 0,4 & 12,51 & 6,51 & $0,00^{* *}$ & 2,62 & 1,82 & 3,42 \\
\hline \multirow{2}{*}{$\underset{\mathscr{W}}{\cup}$} & Male & 10,78 & 4,37 & 0,55 & 7,35 & 6,22 & $0,00^{* *}$ & 3,43 & 2,33 & 4,53 \\
\hline & Female & 11,86 & 4,49 & 0,42 & 9,16 & 6,42 & $0,00^{* *}$ & 2,7 & 1,87 & 3,53 \\
\hline \multirow{2}{*}{ 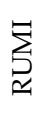 } & Male & 13,76 & 5 & 0,63 & 13,61 & 0,24 & 0,81 & 0,15 & $-1,11$ & 1,42 \\
\hline & Female & 16,2 & 5,35 & 0,5 & 16,68 & $-0,95$ & 0,34 & $-0,48$ & $-1,47$ & 0,52 \\
\hline \multirow{2}{*}{ 焉 } & Male & 8 & 4,87 & 0,61 & 7,17 & 1,35 & 0,18 & 0,83 & $-0,4$ & 2,06 \\
\hline & Female & 10,67 & 4,99 & 0,47 & 8,93 & 3,71 & $0,00^{* *}$ & 1,74 & 0,81 & 2,66 \\
\hline
\end{tabular}

\begin{tabular}{|c|c|c|c|c|c|c|c|c|c|c|}
\hline \multirow{2}{*}{ 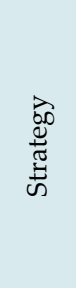 } & \multirow[t]{2}{*}{ 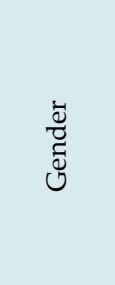 } & \multirow[t]{2}{*}{$\stackrel{\Xi}{\text { ฮี }}$} & \multirow{2}{*}{$\begin{array}{l}\overrightarrow{0} \\
0 \\
\text { Dं } \\
\text { के }\end{array}$} & \multirow{2}{*}{ 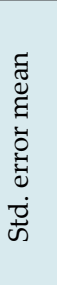 } & \multicolumn{3}{|c|}{ One sample $t$ test } & \multirow{2}{*}{ 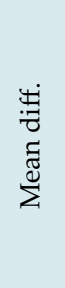 } & \multicolumn{2}{|c|}{$\begin{array}{c}95 \% \\
\text { Confidence } \\
\text { interval } \\
\text { of the } \\
\text { difference }\end{array}$} \\
\hline & & & & & 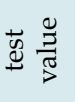 & $\mathrm{t}$ & Sig. & & 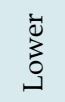 & $\begin{array}{l}\overrightarrow{\tilde{d}} \\
\frac{2}{2}\end{array}$ \\
\hline \multirow{2}{*}{ 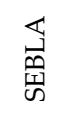 } & Male & 10,67 & 4,6 & 0,58 & 9,81 & 1,48 & 0,14 & 0,86 & $-0,3$ & 2,02 \\
\hline & Female & 12,16 & 5,23 & 0,49 & 11,48 & 1,38 & 0,17 & 0,68 & $-0,29$ & 1,65 \\
\hline \multirow{2}{*}{ 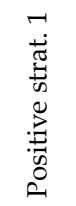 } & Male & 12,54 & 3,2 & 0,4 & 11,08 & 3,62 & $0,00^{* *}$ & 1,46 & 0,65 & 2,27 \\
\hline & Female & 10,31 & 3,83 & 0,36 & 9,09 & 3,4 & $0,00^{* *}$ & 1,22 & 0,51 & 1,93 \\
\hline \multirow{2}{*}{ 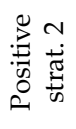 } & Male & 11,76 & 3,35 & 0,42 & 10,06 & 4,03 & $0,00^{* *}$ & 1,7 & 0,86 & 2,54 \\
\hline & Female & 12,54 & 3,63 & 0,34 & 10,69 & 5,44 & $0,00^{* *}$ & 1,85 & 1,18 & 2,52 \\
\hline \multirow{2}{*}{$\begin{array}{l}\sum_{0}^{\infty} \\
0 \\
0 \\
0 \\
0\end{array}$} & Male & 15,96 & 3,63 & 0,46 & 16,27 & $-0,68$ & 0,5 & $-0,31$ & $-1,23$ & 0,6 \\
\hline & Female & 15,35 & 3,56 & 0,33 & 16,1 & $-2,24$ & $0,03^{*}$ & $-0,75$ & $-1,41$ & $-0,09$ \\
\hline \multirow{2}{*}{$\sum_{\substack{0 \\
0 \\
0}}^{0}$} & Male & 13,78 & 2,45 & 0,31 & 12,47 & 4,24 & $0,00^{* *}$ & 1,31 & 0,69 & 1,93 \\
\hline & Female & 13,11 & 2,87 & 0,27 & 11,96 & 4,28 & $0,00^{* *}$ & 1,15 & 0,62 & 1,68 \\
\hline
\end{tabular}




\begin{tabular}{|c|c|c|c|c|c|c|c|c|c|c|}
\hline \multirow{2}{*}{ 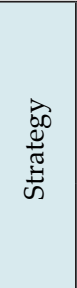 } & \multirow[t]{2}{*}{ 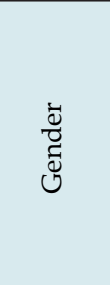 } & \multirow[t]{2}{*}{$\stackrel{\varpi}{\Sigma}^{\varpi}$} & \multirow{2}{*}{$\begin{array}{l}\dot{\vec{z}} \\
\dot{0} \\
\dot{\vec{d}}\end{array}$} & \multirow{2}{*}{ 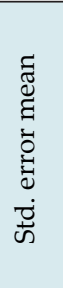 } & \multicolumn{3}{|c|}{ One sample $\mathrm{t}$ test } & \multirow{2}{*}{ 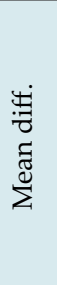 } & \multicolumn{2}{|c|}{$\begin{array}{c}95 \% \\
\text { Confidence } \\
\text { interval } \\
\text { of the } \\
\text { difference }\end{array}$} \\
\hline & & & & & 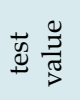 & $\mathrm{t}$ & Sig. & & $\begin{array}{l}\ddot{\Phi} \\
\vdots \\
0 \\
3\end{array}$ & $\begin{array}{l}\bar{\nu} \\
\stackrel{2}{2}\end{array}$ \\
\hline \multirow{2}{*}{ 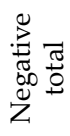 } & Male & 10,8 & 3,8 & 0,48 & 9,49 & 2,74 & $0,01^{* *}$ & 1,31 & 0,35 & 2,27 \\
\hline & Female & 12,72 & 4,2 & 0,39 & 11,56 & 2,95 & $0,00^{* *}$ & 1,16 & 0,38 & 1,94 \\
\hline
\end{tabular}

${ }^{*} \alpha \leq 0.05 ;{ }^{* *} \alpha \leq 0.01 ; N=177 ; d f=176 ;$ abbreviations of coping strategies are explained in Table 2.

Tab. 4: Results - descriptive statistics and one sample t-tests for male and female students vs. respective test value from Czech population sample.

We can see several significant differences in Table 4. In female students we find a significant difference in the use of the strategies Denial of guilt, Distraction, Situation control, Positive Self-instruction and Resignation compared to women from the regular Czech population sample. Male students' scores in these coping strategies were similar to those demonstrated by men in the standardization sample. This more detailed perspective shows that female students more frequently use coping strategies oriented to obtaining social support or denying guilt which are among emotion-focused strategies, but they also more frequently than women in regular population use two of the most appropriate coping strategies, namely Positive selfinstruction and Situation control. Male students only differ from men in the standardization sample of the Czech population in categories in which we also find significant differences in female students compared to women in the standardization sample.

The last part of results presented in this paper consists of a comparison of male students and female students in our university students' sample. The comparison of male students and female students using two adequate sample t-tests is offered in Table 5, with Levene's tests' results assuming equal variances of samples.

\begin{tabular}{|c|c|c|c|c|c|c|c|c|}
\hline \multirow[t]{2}{*}{ Strategy } & \multicolumn{2}{|c|}{$\begin{array}{l}\text { Levene's } \\
\text { tests }\end{array}$} & \multicolumn{2}{|c|}{$\mathrm{t}$ tests } & \multirow[t]{2}{*}{$\begin{array}{l}\text { Mean } \\
\text { diff. }\end{array}$} & \multirow{2}{*}{$\begin{array}{l}\text { Std. } \\
\text { error } \\
\text { diff. }\end{array}$} & \multicolumn{2}{|c|}{$\begin{array}{c}95 \% \\
\text { Confidence } \\
\text { interval } \\
\text { of the } \\
\text { difference }\end{array}$} \\
\hline & $\mathrm{F}$ & Sig. & $\mathrm{t}$ & Sig. & & & $\begin{array}{l}\overrightarrow{0} \\
3 \\
0 \\
\end{array}$ & مेّ̆ \\
\hline MIN & 0,07 & 0,80 & 4,91 & $0,00^{* *}$ & 3,81 & 0,78 & 2,28 & 5,34 \\
\hline DENGU & 0,93 & 0,34 & 1,04 & 0,30 & 0,65 & 0,63 & $-0,59$ & 1,90 \\
\hline DISTR & 0,24 & 0,62 & $-1,05$ & 0,30 & $\mid-0,67$ & 0,63 & $-1,92$ & \begin{tabular}{|l}
0,59 \\
\end{tabular} \\
\hline SUB & 0,62 & 0,43 & $-1,32$ & 0,19 & $-0,89$ & 0,67 & $-2,22$ & 0,44 \\
\hline SITCON & 0,13 & 0,72 & 0,09 & 0,93 & 0,06 & 0,65 & $-1,22$ & 1,33 \\
\hline RECON & 0,08 & 0,78 & 1,77 & 0,08 & 1,05 & 0,60 & $-0,12$ & 2,23 \\
\hline POSI & 1,19 & 0,28 & 0,94 & 0,35 & 0,70 & 0,74 & $-0,77$ & 2,17 \\
\hline SOCSUP & 1,12 & 0,29 & $-3,22$ & $0,00^{* *}$ & $-2,46$ & 0,77 & $-3,97$ & $-0,95$ \\
\hline AVOID & 0,01 & 0,91 & $-0,24$ & 0,81 & $-0,16$ & 0,68 & $-1,51$ & 1,18 \\
\hline ESC & 0,00 & 0,98 & $-1,55$ & 0,12 & $-1,08$ & 0,70 & $-2,46$ & 0,30 \\
\hline RUMI & 0,19 & 0,66 & $-2,97$ & $0,00^{* *}$ & $-2,44$ & 0,82 & $-4,06$ & $-0,82$ \\
\hline RES & 0,09 & 0,77 & $-3,43$ & $0,00^{* *}$ & $-2,67$ & 0,78 & $-4,20$ & $-1,13$ \\
\hline SEBLA & 1,28 & 0,26 & $-1,89$ & 0,06 & $-1,49$ & 0,79 & $-3,05$ & 0,06 \\
\hline $\begin{array}{l}\text { Positive } \\
\text { strategies } 1\end{array}$ & 2,72 & 0,10 & 3,93 & $0,00^{* *}$ & 2,23 & 0,57 & 1,11 & 3,35 \\
\hline
\end{tabular}




\begin{tabular}{|c|c|c|c|c|c|c|c|c|}
\hline \multirow[t]{2}{*}{ Strategy } & \multicolumn{2}{|c|}{$\begin{array}{l}\text { Levene's } \\
\text { tests }\end{array}$} & \multicolumn{2}{|c|}{$\mathrm{t}$ tests } & \multirow[t]{2}{*}{$\begin{array}{l}\text { Mean } \\
\text { diff. }\end{array}$} & \multirow{2}{*}{$\begin{array}{l}\text { Std. } \\
\text { error } \\
\text { diff. }\end{array}$} & \multicolumn{2}{|c|}{$\begin{array}{c}95 \% \\
\text { Confidence } \\
\text { interval } \\
\text { of the } \\
\text { difference }\end{array}$} \\
\hline & $\mathrm{F}$ & Sig. & $\mathrm{t}$ & Sig. & & & 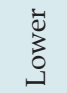 & 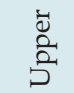 \\
\hline $\begin{array}{l}\text { Positive } \\
\text { strategies } 2\end{array}$ & 0,86 & 0,35 & $-1,40$ & 0,16 & $-0,78$ & 0,55 & $-1,87$ & 0,32 \\
\hline $\begin{array}{l}\text { Positive } \\
\text { strategies } 3\end{array}$ & 0,25 & 0,62 & 1,07 & 0,29 & 0,60 & 0,56 & $-0,51$ & 1,72 \\
\hline $\begin{array}{l}\text { Positive } \\
\text { total }\end{array}$ & 0,92 & 0,34 & 1,58 & 0,12 & 0,67 & 0,43 & $-0,17$ & 1,52 \\
\hline $\begin{array}{l}\text { Neutral } \\
\text { total }\end{array}$ & 2,34 & 0,13 & $-2,32$ & $0,02^{*}$ & $-1,31$ & 0,57 & $-2,43$ & $-0,20$ \\
\hline $\begin{array}{l}\text { Negative } \\
\text { total }\end{array}$ & 1,10 & 0,30 & $-3,01$ & $0,00^{* *}$ & $-1,92$ & 0,64 & $-3,18$ & $-0,66$ \\
\hline
\end{tabular}

${ }^{*} \alpha \leq 0.05,{ }^{* *} \alpha \leq 0.01, N$ male $=63, N$ female $=114, d f=175$ for each $t$ test; descriptive statistics is shown in Table 4; abbreviations of coping strategies are explained in Table 2.

Tab. 5: Results - descriptive statistics and two independent samples t-tests for each coping strategy, with Levene's tests for equality of variances.

Results presented in Table 5 show a significant difference in the use of the strategies Minimization, Social support, Rumination and Resignation. Looking at average values, we can also observe direction of the difference, and it is obvious that the Minimization strategy is more frequently used by male students in our sample, while the remaining strategies - Social Support, Rumination and Resignation are more frequently used by female students. Like in the previous case, these results correspond with the concept mentioned by Lazarus and Folkmann (1984), partially also by Lukavský, Šolcová and Preiss (2011). The coping strategies results also manifested in the comparison of different groups of positive coping strategies (Positive strategies 1, Positive strategies 2 and Positive strategies 3 ), as well as in the comparison of positive, neutral and negative strategies in total. Similarly as with individual coping strategies, also in this case we can see significant differences in the first group of coping strategies (probably significantly influenced by the Minimization strategy), in the group of neutral strategies (probably influenced by a significant difference in the Social support coping strategy), as well as in the group of negative strategies (particularly due to significant differences in the strategies Rumination and Resignation).

\section{Discussion}

According to Dömeová, Vostrá and Jindrová (2011) most graduates and students of the Faculty of Economics and Management (FEM) are women; the question for further research should be, that this fact might be associated with men and women using certain strategies which are likely to be more effective with respect to their studies. Our student sample is not representative in this regard - both genders were almost equally represented in part-time students, which does not correspond with the actual situation at FEM - the proportion of full-time male and female students better captures FEM.

Some contemporary stress researchers view the role of gender as follows: it may come into play at each phase of the stress experience, determining exposure to events and appraisal of those events as stressful as well as influencing physiological responses and coping efforts. It also may moderate the relation between stress and health outcomes, such that even when 
stress is comparable, one gender is more vulnerable to negative outcomes (Davis, Burleson and Kruszewski, 2011).

Authors of this study are aware, that following the modern stress science research methods, other, alternative psychometric tools could also be used to identify coping strategies. Shankland et al. (2010) assessed students' adaptation to a different type of education with the use of a test battery containing the Coping Inventory for Stressful Situations by Endler and Parker as one of the tools Šolcová, Lukavský and Greenglass (2006) used for their research of proactive stress coping strategies the Proactive Coping Inventory. In an earlier research of stressogenic situations in university students in the Czech environment, Millerová, Michálek and Franco Ruiz (2007) used an adapted version of the Stress Profile questionnaire. As mentioned above, authors of this study chose the questionnaire tool SVF 78 as the primary method for measuring coping strategies in students (similarly to Janke and Erdmann, 2003 or Balcar, Trnka and Kuška, 2011). In addition to other advantages, such as group administration and prompt, well-arranged assessment, authors also opted for this questionnaire with respect to topics discussed in contact lessons, with the analyzed coping strategies smoothly following the lessons' content concerning Mental hygiene, health psychology and Personality psychology lectures.

\section{Conclusion}

The most important outcome of the current study research is a proven significant distinction between the positive-negative stress coping strategies employed by CULS undergraduate students and those of the Czech population sample. Although authors suggest further study on a larger, and especially in gender and educational background better balanced sample of respondents, high number of negative stress coping techniques used by undergraduate university students in this study undoubtedly requires certain measures to be taken into consideration. From the global point of view, the use of positive stress coping techniques seems comparatively high and might therefore be considered as satisfactory. However, significantly lower use of the most constructive and, in longer prospective, most approved group of strategies is rather disappointing. It seems highly sensible to offer students alternative strategies of coping with stress emerging from work, family, and school demands. Cohen et al. (1993) stresses stress-elicited changes in health practices such as smoking and alcohol consumption, which may represent an obvious danger to the students. Coping styles are generally considered to be environmentally driven. Up to now, research has mainly focused on family influences. However, some studies (Shankland et al., 2009) underline the effect of educational settings on the development of problemfocused coping strategies. Presently, there are Mental hygiene seminars accessible to full-time students, where they may be given a chance to experience and try out different relaxation techniques. Authors believe that such option should be offered to all students of the Czech University of Life Sciences.

For students in acute distress situations Department of Psychology offers free counselling services.

\section{Acknowledgements}

This research was supported by the grant from Czech Science Foundation number P407/10/1262, for years 2010-2012.

\section{References}

Aldwin, C. M. and Yancura, L. „Stress, Coping, and Adult Development" In Contrada, R. J. and Baum, A. (2011) The 
Handbook of Stress Science, New York: Springer Publishing Company.

Balcar, K., Trnka, R. and Kuška, M. (2011) „How many ways to deal with stress? Stress coping factors in the SVF 78", Activitas Nervosa Superior, vol. 53, no. 1/2, pp. 27-34.

Chamoutová, K. and Chýlová H. (2008) „Coping with stress at CULS students - a Comparison study" Proceedings of the 5thInternational Conference on Efficiency and Responsibility in Education (ERIE 2008), Prague, pp. 88-91.

Carver, C. S. et al. (1989) "Assessing coping strategies: A theoretically based approach,", Journal of Personality and Social Psychology, vol. 56, no. 2, pp. 267-283. http://dx.doi. org/10.1037/0022-3514.56.2.267

Cohen, S. et al. (1993) „Negative Life Events, Perceived Stress, Negative Affect, and Susceptibility to the Common Cold", Journal of Personality and Social Psychology, vol. 64, no. 1, pp. 131 - 140. http://dx.doi.org/10.1037/0022-3514.64.1.131

Contrada, R. J. and Baum, A. (eds.) (2011) The Handbook of Stress Science, New York: Springer.

Davis, M. C., Burleson, M. H. and Kruszewski, D. M. (2011) "Gender: Its Relationship to Stressor Exposure, Cognitive Appraisal/Coping Processes, Stress Responses, and Health Outcomes" In Contrada, R. J. and Baum, A. (2011) The Handbook of Stress Science, New York: Springer Publishing Company.

Disman, M. (2008) Jak se vyrábí sociologická znalost, Praha: Karolinum.

Dömeová, L., Vostrá, H. and Jindrová, A. (2011) „Comparison of Full Time and Combined Studies with Gender Aspect", Journal on Efficiency and Responsibility in Education and Science, vol. 4, no. 1, pp. 31-45.
Eduardo Piemontesi, S. et al. (2012) „Test anxiety and coping styles with academic stress in university students", Anales De Psicologia, vol. 28, no. 1, pp. 89-96.

Gerin, W. „Acute Stress Responses in the Psychophysiological Laboratory" In Contrada, R. J. and Baum, A. (2011) The Handbook of Stress Science, New York: Springer.

Horáková, M. (2009) „Výzkum strategií zvládání stresu a jejich vztah k dalším charakteristikám u řidičù záchranné služby", E-psychologie, vol. 3, no. 2, pp. 10-21.

Ising, M. (2006) „Comparing two approaches for the assessment of coping: Part II. Differences in stability in time, , Journal of Individual Differences, vol 27, no. 1, pp. 15-19.

Janke, W. and Erdmann, G. (2003) Strategie zvládání stresu SVF 78, Praha: Testcentrum.

Janke, W. and Erdmann, G. (2005) ,Stressverarbeitungsfragenbogen (2 Auflage),, In: Ising, M. (2006) „Comparing two approaches for the assessment of coping: Part II. Differences in stability in time,,, Journal of Individual Differences, vol 27, no. 1, pp. 15-19.

Kebza, V. (2005) Psychosociální determinanty zdraví, Praha: Academia.

Lazarus, R. S. and Folkman, S. (1984) Stress, appraisal, and coping, New York: Springer.

Lukavský, J., Šolcová, I. and Preiss, M. (2011) „Proaktivní zvládání u osob staršího věku: vztah k vybraným kognitivním proměnným", Československá psychologie, vol. 55, no. 3, pp. 193203.

Millerová, L., Michálek, P. and Franco Ruiz, C. (2007) "Stress Factors of University Students", Proceedings of the 4th 
International Conference on Efficiency and Responsibility in Education (ERIE 2007), Prague, pp. 153-156.

Norušis, M. J. (2011) IBM SPSS Statistics 19 Advanced Statistical Procedures, New York: Pearson.

Saklofske, D. et al. (2012) „Relationships of personality, affect, emotional intelligence and coping with student stress and academic success: Different patterns of association for stress and success," Learning \& Individual Differences, vol. 22, no. 2, pp. 251-257. http://dx.doi.org/10.1016/j.lindif.2011.02.010

Selye, H. (1950) "Stress and the general adaptation syndrome", British Medical Journal, vol. 1, no. 4667, pp. 1383-1392. http://dx.doi.org/10.1136/bmj.1.4667.1383

Shankland, R., et al. (2009) „Preliminary study on the role of alternative educational pathways in promoting the use of problem-focused coping strategies", European Journal of Psychology of Education, vol. 24, no. 4, pp. 499-512. http://dx.doi.org/10.1007/BF03178764

Shankland, R., et al. (2010) „Student adjustment to higher education: the role of alternative educational pathways in coping with the demands of student life", Higher Education, vol. 59, no. 3, pp. 353-366. http://dx.doi.org/10.1007/s10734-009$\underline{9252-7}$

Šolcová, I., Lukavský, J. and Greenglass, E. (2006) „Dotazník proaktivního zvládání životních nárokü“, Československá psychologie, vol. 50, no. 2, pp. 148-162.

Weyers, P. et al. (2005) "Comparing two approaches for the assessment of coping: I. Psychometric properties and intercorrelations", Journal of Individual Differences, vol. 26, pp. 207-212.

Weyers, P., Ising, M. and Janke, W. (2005) „Effects of imagined stress intensity on responses in a stress coping inventory",
Anxiety, Stress and Coping, vol. 18, no. 2, pp. 117-130. http://dx.doi.org/10.1080/10615800500093744 